\title{
Testing long-run relationship between agricultural gross domestic product and fruits production: evidence from Pakistan
}

\author{
Arif Ullah ${ }^{1}$ Dilawar Khan ${ }^{2}$ Shaofeng Zheng ${ }^{*}$ (6)
}

${ }^{1}$ College of Economics and Management, Northwest A\&F University, 3 Taicheng Road, Yangling, Shaanxi 712100, China. E-mail: zsfeng@nwsuaf.edu.cn. .Corresponding author.

${ }^{2}$ Department of Economics, Kohat University of Science \& Technology, Kohat 26000, Pakistan.

\begin{abstract}
This paper analyses the long-run relationship between agricultural gross domestic product (GDP) and fruits production of Pakistan's economy over a period of 1961-2015 by employing Johansen and autoregressive distributed lag (ARDL) modern econometric technique. Three fruits were selected namely mango, apple and peach in this study. Augmented Dickey-Fuller and Phillips-Perron tests were used to check the data stationarity and conclude that the series are integrated of order one. The Johansen approach was applied to check the joint evolution of all the variables for co-integration. The Johansen test suggests that a long-run co-integration exists between agricultural GDP and fruits production. Results of the ARDL model (Bound test) detect the existence of long-run relationship between agricultural GDP and fruits production. The coefficient of the short-run form of ARDL model reveals that all the fruits have a positive impact on agricultural GDP. Moreover, the coefficients of the long-run form of ARDL model have apositive and significant influence on agricultural GDP of Pakistan. These results suggest that a $1 \%$ increase in mango, apple and peach production will increase agricultural GDP by $0.06 \%, 0.03 \%$ and $0.03 \%$ respectively. Finally, forecast error variance decomposition and impulse response function results depict that mango, apple and peach production significantly contributes to agricultural GDP in the case of Pakistan.

Key words: $A R D L$ model, Johansen approach, agricultural GDP, fruits production.
\end{abstract}

Teste de relação de longo prazo entre o produto interno bruto agrícola e produção de frutos: evidência do Paquistão

RESUMO: Este artigo analisa a relação de longa duração entre o Produto Interno Bruto agrícola (PIB) e a produção de frutos na economia do Paquistão durante um periodo de 1961-2015, empregando Johansen e o modelo ARDL (Autoregressive Distributed Lag) técnica de cointegração ou técnica de cointegração vinculada. Três frutas foram selecionadas neste estudo: manga, maçã e pêssego. Testes aumentados de Dickey-Fuller e Phillips-Perron foram utilizados para verificar a estacionária de dados e concluir que a série está integrada na ordem um. A abordagem de Johansen foi aplicada para verificar a evolução conjunta de todas as variáveis para a cointegração. O teste de Johansen sugere que existe uma cooperação de longa duração entre o PIB agrícola e a produção de frutos. Os resultados do modelo ARDL (Bound test) detectam a existência de uma relação de longa duração entre o PIB agrícola e a produção de frutos. O coeficiente da forma de curto prazo do modelo ARDL revela que todos os frutos têm um impacto positivo no PIB agrícola. Além disso, os coeficientes da forma de longo prazo do modelo ARDL têm uma influência positiva e significativa sobre o PIB agrícola do Paquistão. Estes resultados sugerem que um aumento de $1 \%$ na produção de manga, maçã e pêssego irá aumentar o PIB agrícola em 0,6\%, 0,3\% e 0,3\%, respectivamente. Finalmente, a previsão de desvio de erros e resultados da função de resposta de impulso retratam que a produção de manga, maçã e pêssego contribui significativamente para o PIB agrícola do Paquistão. Palavras-chave: modelo ARDL, abordagem Johansen, PIB agricola, produção de frutos.

\section{INTRODUCTION}

Agriculture plays a major role in Pakistan's economy. This sector has traditionally sustained a satisfactory growth to ensure food security for the growing population (GOP, 2016). Pakistan was primarily based on agriculture at the time of independence. However, as a result of industrial development, the country turned out into the more diversified economy. Nonetheless, 
industrialisation could not eliminate the existence of agriculture in Pakistan but the agricultural share decreased significantly (RAZA et al., 2012). Therefore, the contribution of agriculture in Pakistan economic development cannot be ignored and this country is still known as agrarian country. The main occupation and source of income of the rural population in the country is agriculture. Even though, it is the main sector of the Pakistan economy and creates employment opportunities (ATIF et al., 2016). The last three and half decade's sectoral share of Pakistan GDP is presented in table 1 . The table shows that over a long period of time agriculture contributes significant share to GDP and provision of employment to the population of the country. The recent figure $(42.3 \%)$ show that it is the largest sector in term of employment generations. However, it contributes $19.8 \%$ share to Pakistan GDP and considered as the third main sector of the economy (GOP, 2016). Livestock, horticulture and fisheries are the main sub-sector of Pakistan's agriculture and have a significant role to enhance the GDP of the country.

Within agriculture, the horticulture is an important sub-sector of agriculture. Pakistan's ecologies have natural climate zones, which are rich to produce horticultural crops. In addition, by adopting excellent methods of cultivation, farmers having small land can become self-sufficient in horticultural produce (GOP, 2010). Fruits contribute $2.48 \%$ value addition to agricultural GDP of Pakistan (GOP, 2016). Pakistan's horticulture sector produces approximately 12 million tonnes per year production of fruits, vegetables and spices. High value and great potential fruits are grown in different varieties and delicious in taste. These include apples, mangoes, peaches, grapes, citrus (kinnow), dates, cherries loquat, pears, plums, and guava. These fruits have huge export potential and contribute directly to agriculture GDP of the country (PHDEC, 2017). Horticulture in Pakistan has emerged an important sector contributing to the national agricultural GDP with $12 \%$ share during the last decade and produces a large number of horticultural products to fulfil the domestic demand of fruits and vegetables for the increasing population. The demand for fruits and vegetables is continuously increasing in local and export markets. Global horticulture exports reached $\$ 124$ billion and Pakistan marginally contributed with the worth of $\$ 0.24$ billion with far less than one percent share in world export (AKHTAR et al., 2013).

Nobody can deny the importance of horticultural produces in the human diet. Fruits are nutritious, refreshing and appetising in nature. They are rich in sugar and low in protein. Fruits are a rich source of mineral and vitamins and considered as a protective food (KHAN \& SHAUKAT, 2006). With the passage of time, due to rapid population growth and consumption pattern of the society, the demand for fruits is increasing in Pakistan. Moreover, fruits provide a significant portion of the diet and easily digestible (AUJLA et al., 2007). Data showed that the per capita food supply of fruits in Pakistan has increased from $13.86 \mathrm{~kg} / \mathrm{annum}$ to $14.09 \mathrm{~kg} / \mathrm{annum}$ during the period 1970-2013 (FAOSTAT, 2017).

The climatic diversity of Pakistan is such that it favours cultivation of mango, apple and peach. Apple and peach are temperate fruits while mango is tropical fruit. The southern part of the country has a tropical climate and is suitable for tropical fruits. However, the northern areas in Khyber Pakhtunkhwa and Balochistan province are favourable for temperate fruits (KHAN \& SHAUKAT, 2006).

The mango is one of the most commercialised fruit in tropical countries and it is

Table 1 - Sectoral share in GDP and employment (1980-2016).

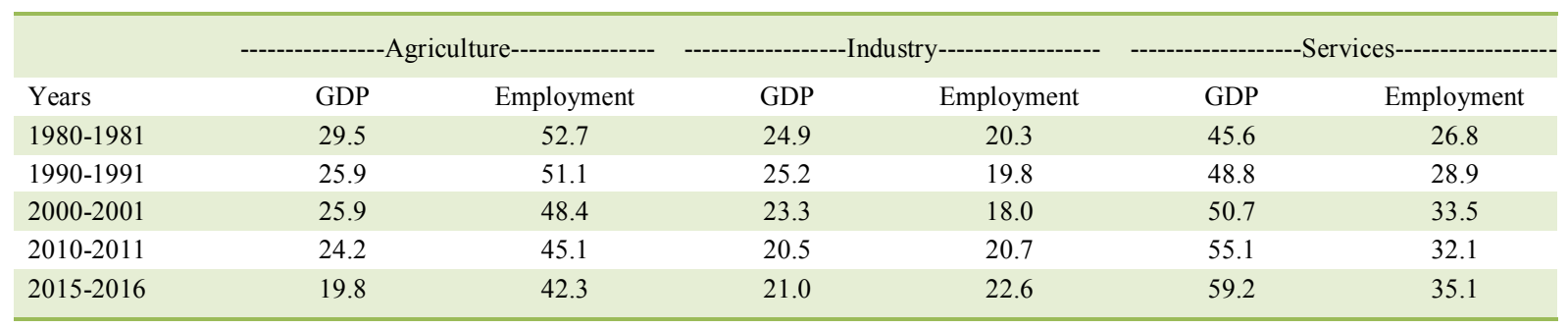

Source: Economic survey of Pakistan. 
considered the king of fruits (PULIDO et al., 2017). Pakistani mangoes are very famous in the world market due to its characteristics and sweet taste. It contains antioxidant vitamins and also a rich source of vitamins $\mathrm{A}, \mathrm{B}$ and $\mathrm{C}$. The other characteristics of this fruit are small amount of carbohydrates, calcium, iron, potassium and protein. However, it is high in fibre content and low in protein. It is the second largest fruit crop of Pakistan in term of production. Pakistan is among the leading mango producer country as it produces 1.8 million tonnes per year. On the basis of its production, Pakistan is considered a natural and original habitat for Mangoes (MEMON, 2016). Nonetheless, in Pakistan, in the year 2012-13, the mango export increased from 103487.34 tonnes to 86001.37 tonnes in 2013-14. In 2014-15, it was grown on an area of 170.8 thousand hectares with production 1716.9 thousand tonnes (GOP, 2015). Worldwide Pakistani mangoes are very famous among the consumer. However, in recent times this industry is unable to supply the acquired amount of fruit, both in quality and quantity around the world on consistent basis. Moreover, the area under mango crop has increased to some extent but the rise in its production is comparatively low. The main causes of low production are poor crop management practices as well as poor pest management practices. In addition, improper post harvest practices such as grading, handling and storage are also a major factor in mangoes low production. Due to post harvest (over-ripe, immature and damaged) losses about $70 \%$ of mangoes fruit in the supply chain being unsalable (ACIAR, 2013).

Apple is the well-known fruit throughout the world. Apple is considered to be the most nutritive fruit as it contains essential food elements like carbohydrates $14.9 \%$, protein $0.3 \%$, sugar $11 \%$, fats $0.4 \%$ and vitamins A, B \& $\mathrm{C}$ in balanced form (MEMON, 2014). In 2014-15 the total production of apple was 617.2 thousand tonnes and cultivated area of apple was 100.4 thousand hectares in Pakistan. However, the area under apple in 2013-14 was 105.2 thousand hectare and production were 606.1 thousand tonnes (GOP, 2015). Worldwide, the total production of apple were seventy-five billion tonnes during 2012, out of which 8.2 million tonnes i.e. more than $10 \%$ have a net worth of $\$ 8$ billion were internationally traded in fresh form. While in 2012-13, Pakistan apple exports were 1,280 tonnes and declined to 521.14 tonnes in $2013-14$ in term of quantity (MEMON, 2014).
Peach is the second most important stone fruit in Pakistan and it is considered the queen of the fruits. It is a remarkable fruit having different attributes i.e. sweetness, juiciness, fleshiness, attractive in flavour and aroma. Due to these attributes, it is very delicious in taste (YU et al., 2015). Fresh peach is comprised of very healthy nutrient. It has a rich source of vitamins $\mathrm{A}$ and $\mathrm{C}$ and also contains potassium and fibre. The fruit has over $80 \%$ water and one average sized peach has $7 \%$ of the dietary fibre which is required each day (HABIB, 2015). In spite of its various uses, its cultivation is declining day by day both in acreage and yield. In Pakistan and especially in northern parts of the country, there is huge scope for promotion of peaches which can be aimed at international marketing by promoting processing industry for value addition and export.

Therefore, it has a huge potential for the home market as well as for the exports (HABIB, 2015). However, Pakistan has experienced ups and downs in peach production. Moreover, farmers do not know the future prospect of peach production and prices while deciding to cultivate this and other crops. The total area under fruits cultivation was 764.26 thousand hectares for the year 2014-15 in Pakistan. Out of the total area under fruits, 5.7 thousand hectares is under peach. The total fruits production was 7018 thousand tonnes among them peach fruit contributes 66.4 thousand tonnes for the year 2014-15 in Pakistan (GOP, 2015). However, in recent time, peach cultivation has been suffering from various problems, such as diseases attacks, low yields, marketing of produce, the high cost of inputs, energy crises, and lack of cold storages, lack of capital, drought causes, and environmental changes that decreased the area under peach orchards.

It is undeniable that 'regional' factors have a substantial impact on shaping activities in the economy as a whole. It would be reasonable to assume that the level of a certain activity (e.g. mango, apple and peach production) in a region has long-run relationship with total agriculture GDP. An intriguing problem is how to identify a region that 'shapes' selected fruits production have relationships with agriculture GDP. A useful approach is provided by co-integration analysis.

This paper investigates the long-run relationship between agriculture GDP and the three selected fruits (mango, apple and peach) production by the nonlinear autoregressive distributive lag (ARDL) model and Johansen technique for 
co-integration in the case of Pakistan. In this perspective, this study analyses the Bounds test to confirm the long-run existence of co-integration between agriculture GDP and the three selected fruits outputs. Imposing co-integrating restrictions improves forecasting power, especially in models which exhibit strong evidence of co-integration between variables. Furthermore, we also examined the forecast-error variance decomposition technique, because it is important to identify the long-run coefficients for each of the analysed fruits outputs. This point of view makes significant contributions, especially in the context of agricultural GDP and economic policy. The relation between agriculture GDP and the production of the selected fruit is applied by three stages. Firstly, the Johansen method is applied. Secondly, this study used the nonlinear ARDL method. Thirdly, the forecast error variance decomposition technique proposed by PESARAN and SHIN (1998) is utilised to test the strength of the analysis. The forecast error variances of agriculture GDP and the production of the selected fruitsare decomposed into proportions which are attributed to shocks in all variables in the vector autoregressive (VAR) system including the agriculture GDP itself. The remainder of the paper proceeds as follows: Section 2 defines materials and methods and data used in the study. In Section 3, the results obtained from the estimated models are discussed. Finally, Section 4 provides concluding remarks.

\section{MATERIALS AND METHODS}

This study is based on the time series data to examine the relationship between the agricultural GDP and the production of three selected fruits (mango, apple and peach) of Pakistan. The variables included in the study are agricultural value added to GDP at 2010 constant US million-dollar (AGD) prices, mango (MAN), apple (APP) and peach (PEA) production in thousand tonnes, annually covering the period 1961 to 2015 . The three selected fruits production data were taken from the Federal Bureau of Statistics and MINFAL (Ministry of food, agriculture and livestock) and AGD data was collected from the World Bank Development Indicator (WDI) website. All the variables were transformed to natural logarithm form. EViews software version 9 was used for data processing and econometric analysis.

We start our analysis to examine the stationarity of time series data. For this purpose, we employed Augmented Dickey-Fuller (1979) (ADF) and Phillips-Perron (1988) (PP) unit root tests. The importance of the PP test due to its robustness over time dependent heteroscedasticities and has the quality to detect variety of serial correlation. If all the series are integrated of order one, then in the next phase we checked the cointegration among the variables.

When the series are integrated of order one the Johansen (1991) cointegration test is used to confirm the existence of long-term relationship between agricultural GDP and respective fruits production. The number of cointegrated equations reveals the reliability of the test for long-term cointegration. The Johansen cointegration consist of Trace $\left(\mathrm{J}_{\text {Trace }}\right)$ and Max-Eigenvalue $\left(\mathrm{J}_{\text {Max }}\right)$ tests. The mathematical expression of these tests is given below:

$$
\begin{aligned}
& \mathrm{J}_{\text {Trace }}(\mathrm{m})=-\mathrm{T} \underset{i=m+1}{\mathrm{a}} \ln \left(1-\lambda_{i}\right) \\
& \mathrm{J}_{\text {Max }}(\mathrm{m}+1)=-\mathrm{T} \ln \left(1-\lambda_{\mathrm{m}+1}\right)
\end{aligned}
$$

Where $\mathrm{T}$ denotes the size of the sample and $\lambda$ presents the estimated value for the $i^{\text {th }}$ ordered. Eigen value from the matrix of $\Pi$, whereas " $\mathrm{m}$ " is used to indicate the cointegrating vectors numbers under the hypothesis. $\mathrm{J}_{\text {Trace }}$ test $(\mathrm{m})$ is conducted to test the hypothesis $\mathrm{H}_{0}$ : rank $\Pi \leq \mathrm{m}$ against $\mathrm{H}_{1}$ : rank $\Pi>\mathrm{m} . \mathrm{J}_{\mathrm{Max}}(\mathrm{m}+1)$ is incorporated here to test the hypothesis $\mathrm{H}_{0}$ : rank $\Pi \leq \mathrm{m}$ against $\mathrm{H}_{1}$ : $\operatorname{rank} \Pi=\mathrm{m}+1$.

The next method we employed in our study is known as ARDL model and initially generated by PESARAN et al. (2001). This model follows OLS estimation procedure for cointegration in order to generate the short-run and long-run coefficient simultaneously. The superiority and application of this technique are useful due to its adoption of multiple integrated variables. Suppose, if the variables in this study are integrated of order zero denoted by $\mathrm{I}(0)$ or integrated of order one denoted by I(1) or mutually cointegrated than we may employ ARDL model. However, this technique fails in the case of any variable integrated of order two denoted by I(2). Therefore, in this situation ARDL model is the best choice model. Additionally, this study aims to investigate the contribution of three fruits production variables on a single dependent agricultural GDP variable so this model becomes more fit in the given circumstances. The linear combination of the variables is given as below:

$\mathrm{AGD}=f(\mathrm{MAN}, \mathrm{APP}, \mathrm{PEA})$

The linear combination is converted into a log-linear model which would present suitable 
and proficient outcomes as compared to the simple linear model.

$\ln A G D_{t}=\beta_{0}+\beta_{1} \operatorname{lnMAN}{ }_{t}+\beta_{2} \ln A P P_{t}+\beta_{3} \operatorname{InPEA}{ }_{t}+\varepsilon_{t}(4)$

The standard ARDL model can be specified as follows:

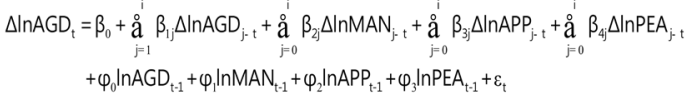

In Eq. (5) $\Delta$ is the first difference operator, $\beta$ and $n$ represent the intercept term and the lag lengths respectively whereas $\varepsilon_{t}$ is serially independent random errors with zero mean and constant variance. The optimal lags (equation 6) of the ARDL model are chosen based on the Schwarz information criteria. The Bound test proposed by PESARAN et al. (2001) based on F-test on the joint null hypothesis. The null hypothesis is determined as $H_{0}: \varphi_{0}=\varphi_{1}=\varphi_{2}=\varphi_{3}=0$ against the alternative hypothesis as $\mathrm{H}_{1}:\left\{\varphi_{0} \neq 0\right\} \mathrm{U}\left\{\varphi_{1} \neq 0\right\} \mathrm{U}\left\{\varphi_{2} \neq 0\right\} \mathrm{U}$ $\left\{\varphi_{3} \neq 0\right\}$ of cointegration among the variables. The null hypothesis is rejected, when the calculated $\mathrm{F}$ value is greater than upper critical bound while accepted when it is lower than the lower critical bound regardless of the $\mathrm{I}(0)$ or $\mathrm{I}(1)$. However, the cointegration test is inconclusive if the computed F-statistic value falls within the upper and lower critical bounds.

$\left(1-\alpha_{1} L-\ldots-\alpha_{k} L^{k}\right) A G D_{t}=\beta_{0}+\left(1-\beta_{1} L-\ldots \beta_{1} L^{2}\right) M A N+\left(1-\gamma_{1} L-\ldots \gamma_{m} L^{m}\right) A P P_{t}+\left(1-\xi_{1} L-\ldots \xi_{n} n^{n}\right) P E A_{t} \quad$ (6)

Following equations $7 \& 8$, it is possible to determine short and long-run coefficients of the ARDL model in order to analyse the relationship between agricultural GDP and the selected fruits (mango, apple and peach) production.

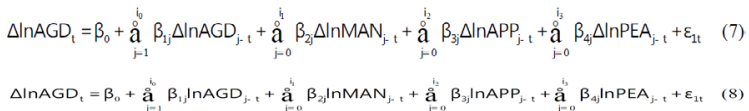

Moreover, in order to check the reliability and stability of the ARDL model we used five residual diagnostic tests. The ARCH (autoregressive conditional heteroskedasticity) test Engle (1982) and Breusch-Godfreyserial correlation LM tests are used to capture the autocorrelation in the residuals. Ramsey RESET (Regression specification error test) was proposed by RAMSEY (1969) to check the misspecification of the model. The CUSUM (cumulative sum of the recursive residuals) test is used to check the stability and credibility of the model (BROWN et al., 1975). JERQUE-BERA (1987) test is used to check the normality of the model.

Finally, based on the Cholesky technique within the VAR model, both the forecast error variance decomposition, as well as impulse response functions, are estimated between the endogenous and exogenous variables. For instant, it shows the proportionate changes in specific variables attributed to the variations in other lagged independent variables. While the impact of shocks to the one explained variable on explanatory variables in the VAR is traced by impulse response function. A shock to a variable in a VAR framework not only directly affects that variable but also transmits its effect to all other endogenous variables in the system.

\section{RESULTS AND DISCUSSION}

Table 2 reports the descriptive statistics of all variables in the study. The agricultural GDP of Pakistan is at 2010 constant US million-dollar prices (AGD). The average value of AGD was 22398.44 million US dollars ranging from 6803.69 to 47086.35 with a standard deviation of 12311.96. The mean value of MAN production was 887.77 thousand tonnes ranging from 224.00 to 1885.90 having a standard deviation of 469.58. Likewise, the average value of APP and PEA production were 247.56 and 29.71 thousand tonnes respectively. The trend of the variables is presented in figure 1 .

The estimated results of the ADF and PP tests are presented in table 3. Both the ADF and

Table 2 - Descriptive statistics of the variables.

\begin{tabular}{lccccc}
\hline Variables & Mean & Median & Maximum & Minimum & Std. Dev. \\
AGD & 22398.44 & 18814.80 & 47086.35 & 6803.69 & 12311.96 \\
MAN & 887.77 & 735.00 & 1885.90 & 224.00 & 469.58 \\
APP & 247.56 & 212.06 & 617.26 & 3.00 & 205.46 \\
PEA & 29.71 & 16.70 & 83.60 & 4.50 \\
\hline
\end{tabular}

Source: Author(s) calculation. 

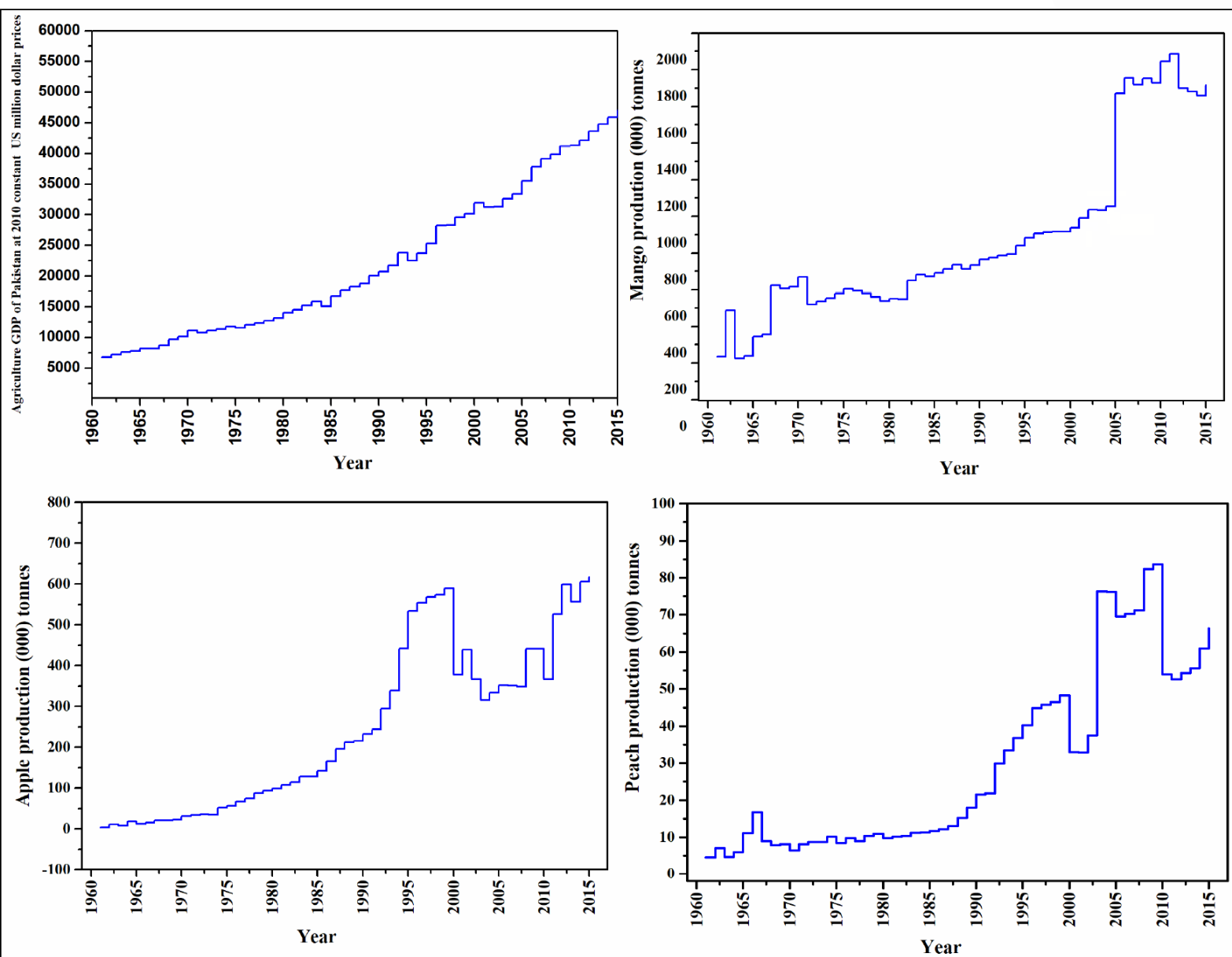

Figure 1 - Trend of the variables in the study.

PP tests values indicate that all the variables were non-stationary at level but become stationary at first difference. These results concluded that all the variables are $\mathrm{I}(1)$.

Since all the variables are integrated of the same order I(1), therefore Johansen co-integration test was employed to assess the hypothesis of cointegration. Table 4 and 5 show the estimated results of Johansen's co-integration (Trace and Max-Eigen) test. The values of Trace statistics is greater than the critical value at $5 \%$ level of significance at least for three cointegrating equations. Thus, the null hypotheses of $H_{0}: k=0, H_{0}: k \leq 1$, and $H_{0}: k \leq 2$ are rejected in favour of alternative hypotheses $H_{1}: k=1$, $H_{1}: k=2$, and $H_{1}: k=3$ in the case of Trace statistics (Table 4). The value of Max-Eigen statistic is greater than the critical value at $5 \%$ level of significance at least for one cointegrating equation. Accordingly, the null hypothesis of $H_{0}: k=0$ is also rejected against the alternative hypothesis $H_{l}: k=1$, in the case of Max-Eigen statistics. Based on these cointegrating equations the presence of long-term cointegration relationship does exist between agricultural GDP and the slected fruits production.

The pre-condition of stationarity in the series are favourable for ARDL model in this study. This means that all the variables are I(1). Consequently, cointegration between agricultural GDP and fruits (mango, apple and peach) production are examined by using the Bound test for cointegration within the ARDL modelling approach. To check the existence of long-run relationship with the help of Wald test we estimate the F-statistics value. It is important to note that F-statistics value 
Table 3 - ADF and PP test for unit root

\begin{tabular}{|c|c|c|c|c|c|c|c|c|}
\hline Variables & & ADF test & $P$ value & Lag & PP test & $P$ value & Lag & Conclusion \\
\hline & Intercept at level & -1.13 & 0.70 & (1) & -0.89 & 0.78 & (1) & $\mathrm{I}(1)$ \\
\hline \multirow[t]{4}{*}{$\ln \mathrm{AGD}$} & Difference & -5.65 & $0.00^{* * *}$ & (1) & -9.17 & $0.00^{* * *}$ & (1) & \\
\hline & Intercept and Trend at level & -2.27 & 0.44 & (1) & -2.69 & 0.24 & (1) & $\mathrm{I}(1)$ \\
\hline & Difference & -5.70 & $0.00^{* * *}$ & (1) & -9.25 & $0.00^{* * *}$ & (1) & \\
\hline & Intercept at level & -2.09 & 0.25 & (2) & -2.02 & 0.28 & (2) & $\mathrm{I}(1)$ \\
\hline \multirow[t]{4}{*}{$\operatorname{lnMAN}$} & Difference & -3.88 & $0.00^{* * *}$ & (2) & -9.96 & $0.00^{* * *}$ & (2) & \\
\hline & Intercept and Trend at level & -3.45 & 0.06 & (2) & -2.02 & 0.28 & (2) & $\mathrm{I}(1)$ \\
\hline & Difference & -3.94 & $0.02^{* *}$ & (2) & -9.96 & $0.00^{* * *}$ & (2) & \\
\hline & Intercept at level & -2.03 & 0.27 & (1) & -2.59 & 0.10 & (1) & $\mathrm{I}(1)$ \\
\hline \multirow[t]{4}{*}{$\ln A P P$} & Difference & -15.00 & $0.00^{* * *}$ & (1) & -13.71 & $0.00^{* * *}$ & (1) & \\
\hline & Intercept and Trend at level & -1.62 & 0.77 & (1) & -1.74 & 0.72 & (1) & $\mathrm{I}(1)$ \\
\hline & Difference & -5.04 & $0.00^{* * *}$ & (1) & -16.02 & $0.00^{* * *}$ & (1) & \\
\hline & Intercept at level & -1.23 & 0.65 & (2) & -1.68 & 0.44 & (1) & $\mathrm{I}(1)$ \\
\hline \multirow[t]{3}{*}{$\ln P E A$} & Difference & -5.13 & $0.00^{* * *}$ & (2) & -7.13 & $0.00^{* * *}$ & (1) & \\
\hline & Intercept and Trend at level & -2.27 & 0.44 & (2) & -3.13 & 0.11 & (1) & $\mathrm{I}(1)$ \\
\hline & Difference & -5.08 & $0.00^{* * *}$ & (2) & -7.06 & $0.00^{* * *}$ & (1) & \\
\hline
\end{tabular}

Asterisk indicates statistical significance. ${ }^{* * *} 1 \%$ level and ${ }^{*} 5 \%$ level.

is sensitive to lag-length. This suggests that it may affect F-statistics. Therefore, it is obligatory to take the optimal lag-length of the variables. In this study, the optimal combination of lag-length values of $\mathrm{k}, \mathrm{l}$, $\mathrm{m}$, and $\mathrm{n}$ in equation (6) is set at 1 . As a result, the optimal lag-length values of $\mathrm{k}, 1, \mathrm{~m}$ and $\mathrm{n}$ are $1,1,1$ and 1 respectively. The results of the estimated value of F-statistics (Bound test for cointegration) are provided in table 6 . The F-critical values are reported in table 6 as taken from Pesaran et al. (2001). The finding reveals thatat lag-length $k=1$ was a suitable combination for cointegration. Table 6 depicts that F-calculated value is greater than the upper critical bound at 5\% significance level. Based on Bounds test estimation of the null hypothesis is rejected $\mathrm{H}_{0}$ : $\mathrm{H}_{0}: \varphi_{0}=\varphi_{1}=\varphi_{2}=\varphi_{3=} 0$ of no cointegration and accepts the alternative hypotheses $\mathrm{H}_{1}:\left\{\varphi_{0} \neq 0\right\} \mathrm{U}\left\{\varphi_{1}\right.$ $\neq 0\} \mathrm{U}\left\{\varphi_{2} \neq 0\right\} \mathrm{U}\left\{\varphi_{3} \neq 0\right\}$ of cointegration.

The deterministic term in the model was specified based on the economic theory and significance of the model. Therefore, restricted intercept and the unrestricted trend were included in the model. The coefficient of short and long-run are estimated in table 7. The estimated constant term is positive and significant at $1 \%$ level. The coefficients of mango, apple and peach production in short-run form are theoretically up to our expectation (positive signed but statistically insignificant). This indicates that mango, apple and peach production has a positive impact on agricultural GDP of Pakistan in short-run. More specifically, a 1\% increase in mango, apple and peach production in Pakistan will increase

Table 4 - Johansen co-integration test using Trace statistics.

\begin{tabular}{lcccccc}
\hline Null Hypothesis & Alternative Hypothesis & Eigen value & Trace Statistic & 5\% Critical value & Prob.* $^{* *}$ Hypothesized No. of CE(s) \\
$H_{0}: k=0$ & $H_{1: k}: 1$ & 0.61 & 92.06 & 54.08 & 0.00 & None $^{*}$ \\
$H_{0}: k \leq 1$ & $H_{1}: k=2$ & 0.32 & 41.55 & 35.18 & 0.00 & ${\text { At most } 1^{*}}^{*}$ \\
$H_{0}: k \leq 2$ & $H_{1}: k=3$ & 0.22 & 21.11 & 20.28 & 0.03 & At most $2^{*}$ \\
$H_{0}: k \leq 3$ & $H_{1}: k=4$ & 0.14 & 7.97 & 9.17 & 0.08 & At most 3 \\
\hline
\end{tabular}

Source: Author(s) calculation. 
Table 5 - Johansen co-integration test using max-Eigen statistics.

\begin{tabular}{lcccccc}
\hline Null Hypothesis & Alternative Hypothesis & Eigenvalue & Max-Eigen Statistic & 5\% Critical value & Prob. $^{* *}$ & Hypothesized No. of CE(s) \\
$H_{0}: k=0$ & $H_{1}: k=1$ & 0.61 & 50.51 & 28.59 & 0.00 & None $^{*}$ \\
$H_{0}: k \leq 1$ & $H_{1}: k=2$ & 0.32 & 20.41 & 22.29 & 0.08 & At most 1 \\
$H_{0}: k \leq 2$ & $H_{1}: k=3$ & 0.21 & 13.11 & 15.89 & 0.12 & At most 2 \\
$H_{0}: k \leq 3$ & $H_{1}: k=4$ & 0.13 & 7.97 & 9.17 & 0.08 & At most 3 \\
\hline
\end{tabular}

Source: Author(s) calculation.

agricultural GDP by $0.04 \%, 0.01 \%$ and $0.02 \%$ respectively. The estimates of the nonlinear model also reveal that changes in the exogenous variables don't have asymmetric significant effects on the AGD in the short-run. It appears that asymmetric effects have also lasted in the long-run. The coefficients of long-run show that mango, apple and peach production have positive and significant influence on the contributions of agricultural GDP of Pakistan. This depicts that a $1 \%$ increase in mango, apple and peach production will increase $0.06 \%, 0.03 \%$ and $0.03 \%$ agricultural GDP of the country. Therefore, we may predict based on these results that mango, apple and peach production will continue their contribution in agriculture GDP of Pakistan in the long-run.

Reliability and stability of the ARDL model were checked with five diagnostic tests. Table 8 highlights the results of the diagnostic tests. The Engle's-ARCH and Breusch-Godfrey reports that the residual is free from autocorrelation problem. Ramsey RESET test value depicts the functional of the model is correct. The Jarque-Bera value shows the model is normal. The cumulative sum together with the $5 \%$ critical lines and results of this test is plotted in figure 2. This test finds that the parameters are stable because the cumulative sum does not exceed beyond the two critical lines. So, CUSUM test predicts that model is stable and credible in its current form.

The results of forecast error variance decomposition are provided in table 9. The firstperiod decomposition for the agricultural GDP in the VAR ordering is completely due to its own innovation. In this case, as the forecast horizon increases the standard errors grow as expected, but tend to level off, suggesting that the system is stationary. Furthermore, in the second horizon shock to agricultural GDP accounts for $97.01 \%$ variation of the fluctuation due to its own shock. Similarly, the shocks to mango, apple and peach production can cause $2.02 \%, 0.42 \%$ and $0.53 \%$ fluctuation in agricultural GDP respectively. These results reveal that agricultural GDP has more influence on mango, apple and peach production after 4-period forecast horizons. Interestingly, agricultural GDP forecast is influenced by all the three selected fruits

Table 6 - The Bounds test for aco-integrating relationship.

\begin{tabular}{|c|c|c|c|c|c|c|}
\hline \multicolumn{5}{|c|}{ 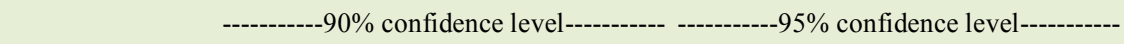 } & \multicolumn{2}{|c|}{------99\% confidence level- } \\
\hline $\mathrm{K}$ & $\mathrm{I}(0)$ & $\mathrm{I}(1)$ & $\mathrm{I}(0)$ & $\mathrm{I}(1)$ & $\mathrm{I}(0)$ & $\mathrm{I}(1)$ \\
\hline 0 & 3.80 & 3.80 & 4.60 & 4.60 & 6.44 & 6.44 \\
\hline 1 & 3.02 & 3.51 & 3.62 & 4.16 & 4.94 & 5.58 \\
\hline 2 & 2.63 & 3.35 & 3.10 & 3.87 & 4.13 & 5.00 \\
\hline 3 & 2.37 & 3.20 & 2.79 & 3.67 & 3.65 & 34.66 \\
\hline 4 & 2.20 & 3.09 & 2.56 & 3.49 & 3.29 & 4.37 \\
\hline 5 & 2.08 & 3.00 & 2.39 & 3.38 & 3.06 & 4.15 \\
\hline \multicolumn{3}{|c|}{ F-statisticDegree of freedom } & & & \multicolumn{2}{|c|}{ P Value } \\
\hline \multicolumn{3}{|c|}{5.74} & \multicolumn{2}{|l|}{$(1,44)$} & \multicolumn{2}{|c|}{0.02} \\
\hline
\end{tabular}

Ciência Rural, v.48, n.5, 2018. 
Table 7 - The ARDL co-integration model.

\begin{tabular}{|c|c|c|c|c|}
\hline Variable & Coefficient & Standard error & t-Statistics & $\mathrm{P}$ value \\
\hline Constant & 3.27 & 1.14 & 2.87 & $0.01^{* *}$ \\
\hline \multicolumn{5}{|c|}{ 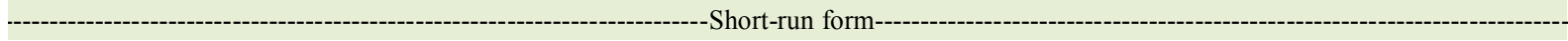 } \\
\hline$\triangle \operatorname{lnMAN}$ & 0.04 & 0.03 & 1.30 & 0.20 \\
\hline$\triangle \ln \mathrm{APP}$ & 0.01 & 0.02 & 0.57 & 0.57 \\
\hline$\triangle \ln P E A$ & 0.02 & 0.02 & 0.79 & 0.43 \\
\hline \multicolumn{5}{|c|}{ 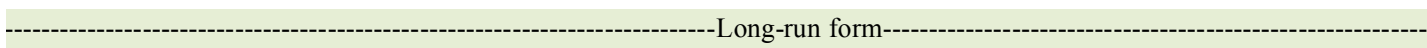 } \\
\hline $\operatorname{lnMAN}$ & 0.06 & 0.03 & 2.02 & $0.05^{* *}$ \\
\hline $\ln \mathrm{APP}$ & 0.03 & 0.01 & 2.14 & $0.04^{* *}$ \\
\hline $\operatorname{lnPEA}$ & 0.03 & 0.02 & 1.70 & $0.10^{*}$ \\
\hline \multicolumn{2}{|c|}{ Akaike Information Criterion (AIC) } & \multicolumn{3}{|c|}{-3.84} \\
\hline \multicolumn{2}{|c|}{ Schwartz Information Criteria (SIC) } & \multicolumn{3}{|c|}{-3.51} \\
\hline \multicolumn{2}{|c|}{ Hannan-Quinn Criteria (HQ) } & \multicolumn{3}{|c|}{-3.72} \\
\hline \multicolumn{2}{|c|}{ Durbin-Watson stat } & \multicolumn{3}{|c|}{2.03} \\
\hline
\end{tabular}

Asterisk indicates statistical significance. ${ }^{* * *} 1 \%$ level, ${ }^{* *} 5 \%$ level and ${ }^{*} 10 \%$ level. Source: Author(s) calculation.

(mango, apple and peach) production. However, apple production has a large impact on agricultural GDP at overall forecasts horizon followed by peach production and to a lesser extent mango production. In conclusion, variation in agricultural GDP is significantly being explained by its own shocks and also by mango, apple and peach production.

Finally, impulse response function checks the effect of a one-time shock to one of the innovations on current and future values of the endogenous variables. Figure 3 shows the impulse response functions analysis based on Cholesky one standard deviation innovation in the error terms. As can be seen from the figure 3 , a one standard deviation shock to agricultural GDP by itself to almost 10-period horizon are significant but gradually decreases with decreasing trend after 4-period horizon. Similarly, one standard deviation shock to apple and peach production is positive and significant, which means that increase in the production of apple and peach would lead to an increase in agricultural GDP of Pakistan. Moreover, the response of mango production to agricultural GDP is positive to the almost 6-period horizon. However, the mango production response after 6-period horizon decreases and interestingly increases after 9-period horizon. It means that the response of mango, apple and peach production to agricultural GDP is positive in the case of Pakistan. The constant increase in this

Table 8 - Residual diagnostic tests.

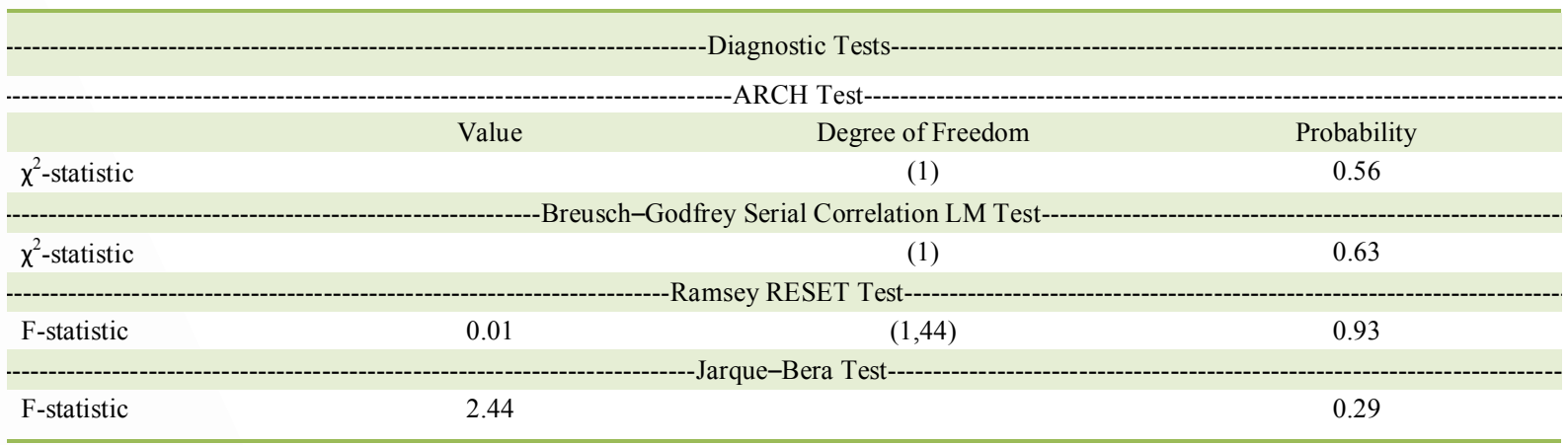

Source: Author(s) calculation

Ciência Rural, v.48, n.5, 2018. 


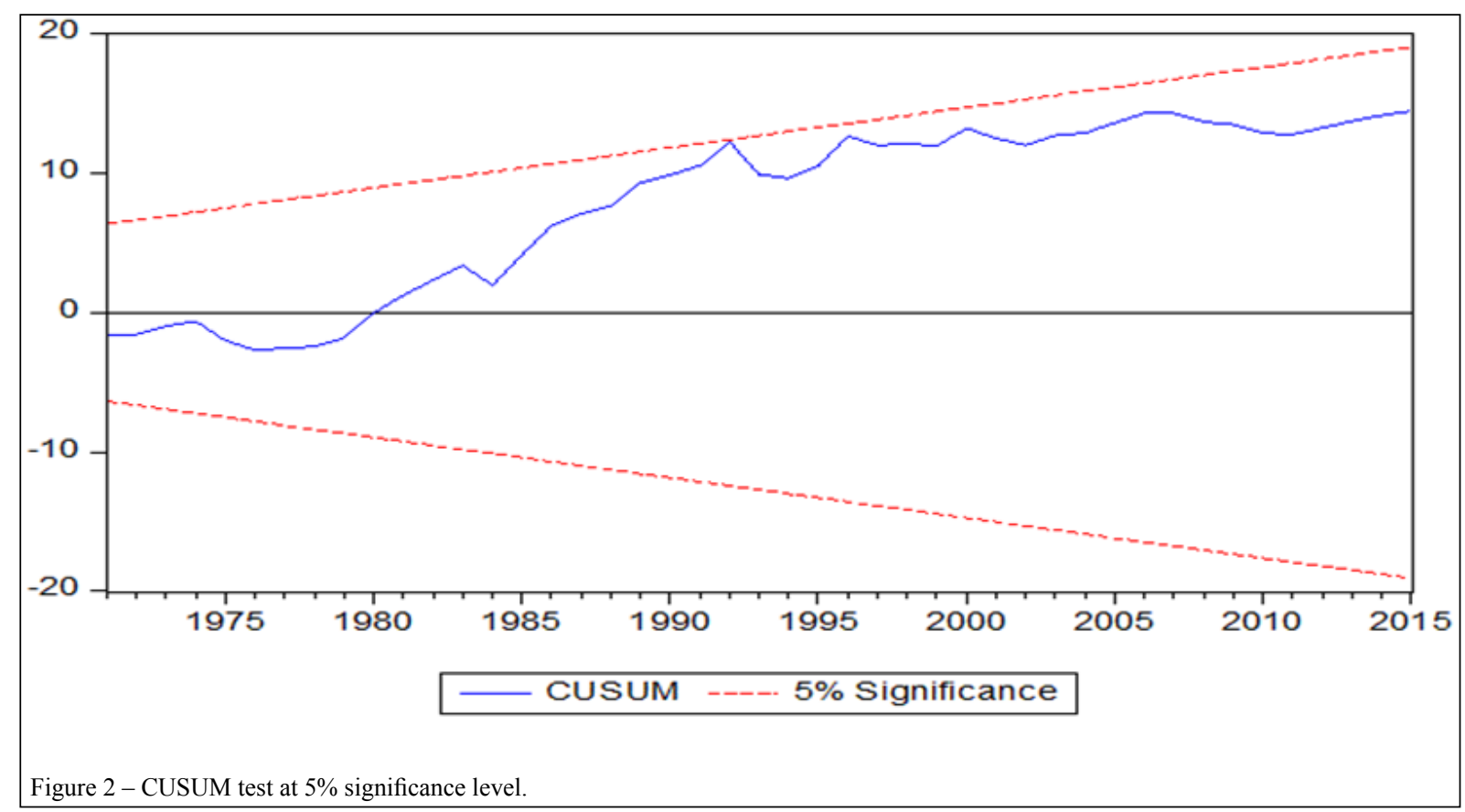

exogenous variable growth shows that there is no danger of possible bubble.

\section{CONCLUSION}

Based on the findings of the study, some key policy implication emerged. First, in the case of Johansen cointegration equations, the presence of long-term cointegration relationship does exist between the fruits production and agricultural GDP of Pakistan. Therefore, policy makers, researchers and government personnel should focus on fruits crops in Pakistan. Second, in the case of ARDL model, it is recommended that fruits production have a robust long-run relationship with agricultural GDP of Pakistan. Consequently, it needs more attention to maintain the long-run relationship in future. In conclusion, this study recommends that to boost export of the country, the government of Pakistan should launch new projects for the development of the

Table 9 - Forecast error variance decomposition.

\begin{tabular}{lccccc}
\hline Periods & S. E & $\ln$ AGD & $\ln$ MAN & $\ln$ APP & ln PEA \\
\hline 1 & 0.32 & 100.00 & 0.00 & 0.00 & 0.00 \\
2 & 0.39 & 97.01 & 2.02 & 0.42 & 0.53 \\
3 & 0.45 & 88.75 & 1.99 & 7.21 & 2.04 \\
4 & 0.50 & 82.42 & 3.71 & 8.88 & 4.97 \\
\hline 5 & 0.56 & 79.16 & 3.06 & 11.40 & 6.32 \\
6 & 0.61 & 79.23 & 2.58 & 11.20 & 6.94 \\
7 & 0.65 & 78.67 & 2.29 & 12.50 & 6.48 \\
8 & 0.69 & 78.72 & 2.11 & 13.20 & 5.91 \\
\hline 9 & 0.72 & 78.69 & 1.92 & 13.90 & 5.46 \\
\hline
\end{tabular}

Source: Author(s) calculation.

Ciência Rural, v.48, n.5, 2018. 


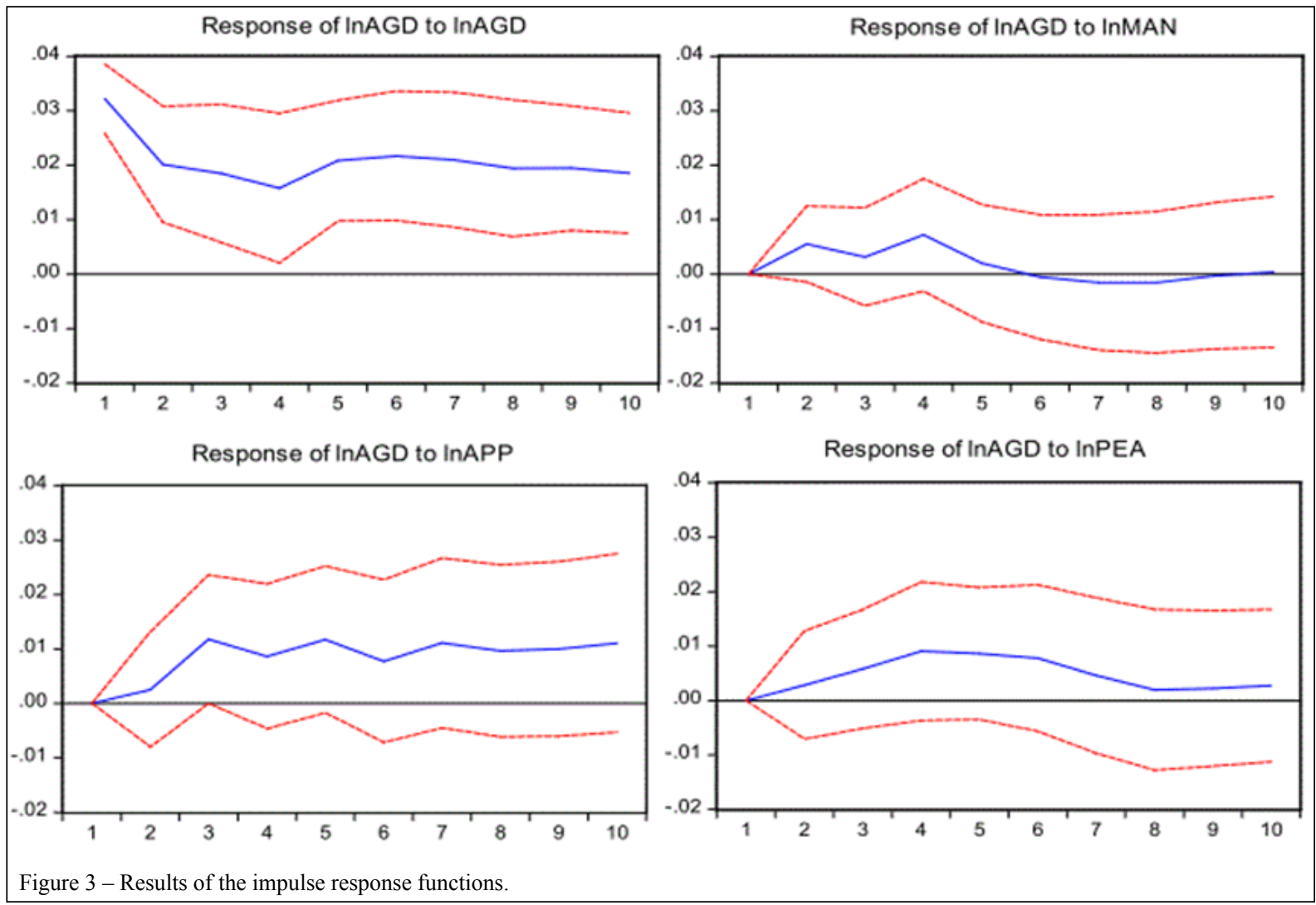

agricultural sector in general and in the horticulture sector in particular.

\section{ACKNOWLEDGEMENTS}

This research was funded by Study on Effectiveness and Operational Mechanism Based on Self-Organizational Control of Regional Fruit Quality. Key Projects of Humanities and Social Science. Research Supported by Northwest A\&F University, China (Grant No. Z109021414).

\section{DECLARATION OF CONFLICT OF INTEREST}

The authors declared no potential conflicts of interest with respect to the research, authorship, and/or publication of this article.

\section{REFERENCES}

ACIAR. Australian Centre for International Agricultural Reseach. Improving market opportunities for mangoes in Pakistan 38 Thynee Street, Fern Hill Park, Bruce ACT Australia, 2013. Available from: <http://aciar.gov.au/files/fs014___mangoes_in pakistan.pdf $>$. Accessed: Nov. 19, 2017.

AKHTAR, W.et al. Export Competitiveness of Pakistani Horticultural Products. Pakistan Journal of Agricultural
Research, v. 26, n. 2,p. 87-96, 2013. Available from: $<$ http://www. pjar.org.pk/PreviousIssue.html>. Accessed: Nov. 19, 2017.

ATIF, R.M. et al. Pakistan's agricultural exports, determinants and its potential: an application of stochastic frontier gravity model. The Journal of International Trade \& Economic Development, v. 26, n. 3, p. 1-20, 2016. Available from: <http://www.tandfonline. com>. Accessed: Nov. 19, 2017.

AUJLA, K.M. et al. Marketing System of Fruits, Margins and Export Potential in Pakistan. Pakistan Journal of life and Social Sciences, v. 5, n. 1-2, p. 34-39, 2007. Available from: <http:// www.pjlss.edu.pk>. Accessed: Nov. 19, 2017.

BROWN, R.L. et al. Techniques for Testing the Constancy of Regression Relationships Over Time. Journal of the Royal Statistical Society, Series B, v. 37, n. 2, p. 149-192, 1975. Available from: <http://pds9.egloos.com/pds/200807/01/78/ CUSUM TEST.pdf>. Accessed: Nov. 19, 2017.

DICKEY, D.A.; FULLER W.A. Distribution of the estimatorsfor autoregressive time series with a unit root. Journal of the American Statistical Association, v. 74, n. 366a, 427-431, 1979. Available from: <http://www.tandfonline.com>. Accessed: Nov. 19, 2017. doi: 10.1080/01621459.1979.10482531.

ENGLE, R.F. Autoregressive Conditional Heteroscedacity with Estimates of variance of United Kingdom Inflation. Econometrica, v. 50, n. 4, p. $987-1008,1982$. Available from: <http://www.econ 
uiuc.edu/ econ536/Papers/engle82.pdf>. Accessed: Nov. 19, 2017.doi:10.2307/1912773.

FAOSTAT, 2017. Food and agricultural Organization. Available from: $<$ http://faostat.fao.org/site /567/DesktopDefault. aspx ?PageID = 567\#ancor. $>$. Accessed: Nov. 19, 2017.

GOP. Government of Pakistan. Economic survey of Pakistan20152016. Finance Division. Economic Adviser's Wing, Islamabad, 2016. Available from: <http://www.finance.gov.pk/>. Accessed: Nov. 19, 2017.

GOP. Government of Pakistan. Fruit, vegetables and condiments statistics of Pakistan2014-2015. Ministry of National Food Security \& research Economic Wing, Islamabad, 2015. Available from: <http://www.amis.pk>. Accessed: Nov. 19, 2017.

GOP. Government of Pakistan. Regulatory procedure for export of horticulture from Pakistan: Small \& Medium Enterprise Development Authority (SMEDA) June 2010. Ministry of Industries and Production, 2010. Available from: $<$ https://www. smeda.org>. Accessed: Mar. 03, 2018.

HABIB, S. Peach: Queen of fruits. Pakistan Food Journal, p. 2627, September-October-2015. Available from: $<$ http://foodjournal. pk>. Accessed: Nov. 19, 2017.

JERQUE, C.M.; BERA, A.K. A test for normality of observations and regression residuals. International Statistical Review, v. 55, p. 163-172, 1987. Available from: <http://onlinelibrary.wiley.com/jou rnal/10.1111/\%28ISSN\%291751-5823>. Accessed: Mar. 03, 2018.

JOHANSEN, S. Estimation and hypothesis testing of cointegration vectors in gaussian vector autoregressive models. Econometrica, v. 59, p. 1551-1580, 1991. Available from: $<\mathrm{http}$ ://onlinelibrary.wiley.com/journal/10.1111/(ISSN)14680262>. Accessed: Mar. 03, 2018.

KHAN, D.;SHAUKAT, S. The fruits of Pakistan: Diversity, Distribution, Trends of production and use. International Journal of Biology and Biotechnology, v. 3, n. 3, p. 463-499, 2006. Available from: <http://www.ijbbku.com>. Accessed: Nov. 19, 2017.

MEMON, N.A. Mango: Pakistan $4^{\text {th }}$ Largest Prodducer in the World. Paistan Food Journal, p. 24-26, March-April-2016. Available from: <http://foodjournal.pk>. Accessed: Nov. 19, 2017.
MEMON, N.A. Apple is a symbol of health. Pakistan Food Journal, p. 34-36, October-November-2014. Available from: $<$ http://foodjournal.pk>. Accessed: Nov. 19, 2017.

PESARAN, H.H.; SHIN, Y. Generalized impulse response analysis in linearmultivariate models. Economics letters, v. 58, n. 1, p. 17 29, 1998. Available from: <http://www.sciencedirect.com/science/ journal/01651765/60>. Accessed: Nov. 19, 2017. doi: 10.1016/ S0165-1765(97)00214-0.

PESARAN, M.H. et al. Bounds testing approaches to the analysis of level relationships. Journal of Applied Econometrics, v. 16, n. 3, p. 289-326,2001. Available from: <http://onlinelibrary.wiley. com>. Accessed: Nov. 19, 2017. doi: 10.1002/jae.616.

PHDEC, 2017. Pakistan Horticulture Development \& Export Company. Ministry of Commerce. Available from: $<$ http://www. phdec.org.pk/phs.php>. Accessed: Apr. 5, 2017.

PHILLIPS, P.C.B.; PERRON, P. Testing for a Unit Root in Time Series Regression. Biometrika, v. 75, n. 2, p. 335-346, 1988. Available from: <https://www.ssc.wisc.edu/ bhansen/718/ PhillipsPerron1988.pdf>. Accessed: Nov. 19, 2017.

PULIDO, R.P.et al. Changes in bacterial diversity of refrigerated mango pulp before and after treatment by high hydrostatic pressure. LWT - Food Science and Technology, v. 78, p. 289-295, 2017. Available from: $<$ http://www.sciencedirect.com/science/article/pii/ S0023643816308350>. Accessed: Nov. 19, 2017.

RAMSEY, J.B. Tests for Specification Errors in Classical Linear Least Squares Regression Analysis. Journal of the Royal Statistical Society, Series B, v. 31, n. 2, p. $350-371,1969$. Available from: <www.jstor.org>. Accessed: Nov. 19, 2017.

RAZA, S.A. Role of Agriculture in Economic Growth of Pakistan. International Research Journal of Finance and Economics, v. $26, n$. 83 , p, 1450 - 2887, 2012. Available from: <http://mpra. ub.uni-muenchen.de>. Accessed: Nov. 19, 2017.

YU, F. et al. Proteomic analysis of postharvest peach fruit subjected to chilling stress or non-chilling stress temperatures during storage. Scientia Horticulturae, v. 197, p. 72-89, 2015. Available from: $<$ http:// www.sciencedirect.com/science/article/pii/S0304423815302739>. Accessed: Nov. 19, 2017. doi: 10.1016/j.scienta.2015.10.045. 